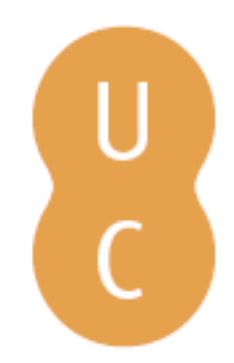

\title{
pommalina
}

\section{National identity and the literary in the globalization era: Canada as case study}

Autor(es): $\quad$ FraileMarcos, Ana María

Publicado por: Imprensa da Universidade de Coimbra

URL

persistente: URI:http://hdl.handle.net/10316.2/43214

DOI: $\quad$ DOl:https://doi.org/10.14195/978-989-26-1483-0_7

Accessed : $\quad$ 26-Apr-2023 10:02:14

A navegação consulta e descarregamento dos títulos inseridos nas Bibliotecas Digitais UC Digitalis, UC Pombalina e UC Impactum, pressupõem a aceitação plena e sem reservas dos Termos e Condições de Uso destas Bibliotecas Digitais, disponíveis em https://digitalis.uc.pt/pt-pt/termos.

Conforme exposto nos referidos Termos e Condições de Uso, o descarregamento de títulos de acesso restrito requer uma licença válida de autorização devendo o utilizador aceder ao(s) documento(s) a partir de um endereço de IP da instituição detentora da supramencionada licença.

Ao utilizador é apenas permitido o descarregamento para uso pessoal, pelo que o emprego do(s) título(s) descarregado(s) para outro fim, designadamente comercial, carece de autorização do respetivo autor ou editor da obra.

Na medida em que todas as obras da UC Digitalis se encontram protegidas pelo Código do Direito de Autor e Direitos Conexos e demais legislação aplicável, toda a cópia, parcial ou total, deste documento, nos casos em que é legalmente admitida, deverá conter ou fazer-se acompanhar por este aviso. 


\section{IDENTITY(IES) A MULTICULTURAL AND MULTIDISCIPLINARY APPROACH}

\section{ANA PAULA ARNAUT \\ (ORG.)}

IMPRENSA DA UNIVERSIDADE DE COIMBRA

COIMBRA UNIVERSITY PRESS 


\title{
NATIONAL IDENTITY AND THE LITERARY \\ I N THE GLOBALIZATION ERA : \\ CANADA AS CASE STUDY
}

Ana María Fraile-Marcos

University of Salamanca

\begin{abstract}
The Canadian nation emerges in the nineteenth century as a self-willing effort at narrating itself. Literature plays an instrumental role in the creation of a system of cultural signification that, as Homi Bhabha points out in Nation and Narration, is by its nature ambivalent. This is even more so at present, when the always on-going process of construction of a unified national identity is encumbered by the centrifugal forces of globalization, linked to the realities of neoliberal late capitalism and instant electronic communication, as well as to the subsequent increase of unfettered mobility, transnationalism, multi-nationalism, and hybridity. This essay draws attention to the present moment as one of change marked by new relations between literature, culture, the state and the way Canadians imagine themselves as a nation in the era of neoliberal capitalist globalization. This moment of crisis, defined by social, economic, political and ideological insecurities calls for a re-evaluation and re-creation of the role of aesthetics and the humanities in the face of global disorder
\end{abstract}


and the dwindling of national sovereignty. In the following pages I track a succession of key moments in the process of identity and cultural building in Canada before illustrating the shifts in the connection between national identity and the Canadian literary with the analysis of Will Ferguson's Scotiabank Giller prizewinner novel 419 (2012).

Keywords: Canada, National Identity Building, Global Novel, Will Ferguson, 419

\section{Globalizing processes are changing Canadian understanding of the national public sphere and the resultant altered relations among poetics, culture, and contending versions of empire. Diana Brydon, Manina Jones, Jessica Schagerl, and Kristen Warder.}

The Canadian nation emerges in the nineteenth century as a self-willing effort at narrating itself. Literature plays an instrumental role in the creation of a system of cultural signification that, as Homi Bhabha points out in Nation and Narration, is by its nature ambivalent. This is even more so at present, when the always on-going process of construction of a unified national identity is encumbered by the centrifugal forces of globalization, linked to the realities of neoliberal late capitalism and instant electronic communication, as well as to the subsequent increase of unfettered mobility, transnationalism, multi-nationalism, and hybridity. Alluding to Hardt and Negri's notion of 'Empire,' the epigraph to this essay draws attention to the present moment as one of change marked by new relations between literature, culture, the state and the way Canadians imagine themselves as a nation in the era of neoliberal capitalist globalization. This moment of crisis, defined by social, economic, 
political and ideological insecurities calls for a re-evaluation and re-creation of the role of aesthetics and the humanities in the face of global disorder and the dwindling of national sovereignty. In the following pages I track a succession of key moments in the process of identity and cultural building in Canada before illustrating with the analysis of Will Ferguson's novel 419 the shifts in the connection between national identity and the Canadian literary.

From its inception in 1867 as 'The Dominion of Canada' - the colony federation of Nova Scotia, New Brunswick, Canada East (Quebec) and Canada West (Ontario) - literature was called in as an indispensable element to confer cohesion, unity and character to an emergent sense of Canadian identity. In 1857 the Irish Nationalist, Catholic spokesman, journalist, and one of the Fathers of the Canadian Confederation, Thomas D'Arcy McGee, for example, saw the emergence of the nation running parallel to the rise of a national literature when he harangued, "Come! Let us construct a national literature for Canada, neither British, nor French, nor Yankeeish, but the offspring and heir of the soil, borrowing lessons from all lands, but asserting its own title throughout all! ("A National Literature for Canada", quoted in Sugars and Moss, 2009: 251). McGee clearly identified the major threats to the nascent national identity, namely, the cultural hegemony embedded in the legacy of the two so-called Founding nations, Britain and France, on the one hand and, on the other, the cultural and economic imperialism of the emerging new world power, the US. In his vision of an autonomous Canadian literature the natural landscape, "the grave mysticism of the Red man, and the wild vivacity of the hunter of western prairies" (Sugars and Moss, 2009: 306) foreshadow the prominence of the Canadian wilderness in the thematic cultural nationalism emerging from English speaking Canada by the time the nation prepared to celebrate its centenary in the 1960 s - in contrast with a more urban focus in Quebec's literary production and criticism. 
Yet, by mid-twentieth century, Canada appeared still uncertain about its identity. The myriad social and political changes underway after World War II highlighted the absence of a unified sense of national identity, something that the government of Louis St. Laurent saw as hampering the nation's cultural maturity and its position as a relevant agent in the world. Believing that culture plays a critically important role in nation building, St. Laurent ordered an inquiry into the state of national development of the arts, letters and sciences. As a result, in 1951 the Massey Commission, or Royal Commission on National Development in the Arts, Letters and Sciences, issued a report advocating the public support of the arts and culture in Canada: '[i]f we in Canada are to have a more plentiful and better cultural fare, we must pay for it. Goodwill alone can do little for a starving plant; if the cultural life of Canada is anemic, it must be nourished, and this will cost money"' (Sugars and Moss, 2009: 204). The Massey report focuses on the need for an increase in funding and government patronage and considers how the arts, research, broadcasting and conservation could be used to foster a sense of national identity. The result was the creation of government sponsored institutions and funding bodies such as the National Library of Canada (1953), the Shakespeare Festival in Stratford, Ontario, McClelland and Stewart's New Canadian Library series of Canadian classic titles, the academic journal Canadian Literature, prizes and fellowships for artists and writers, as well as the funding of Canadian studies abroad. Most important for this purpose was the creation of the Canada Council for the Encouragement of the Arts, Letters, Humanities and Social Sciences in 1957, aimed to "foster Canada's cultural relations abroad, to perform the functions of a national commission for UNESCO, and to devise and administer a system of scholarships" (quoted in Moss and Sugars, 2009: 205). A new generation of writers and artists emerged out of this state-promoted cultural policy - among whom international literary celebrities such as Margaret Atwood, or the 
recent Nobel Prize winner Alice Munro stand out - as well as the new fields of Canadian Studies and Canadian Literature, which were then introduced in the school and university curricula; in addition, these measures fostered the emergence of a national public that sustains a market for 'all things Canadian.' The success of this enterprise can be observed in the words of the 2013 Scotiabank Giller prize winner Linn Coady, who has recently declared she is "proud not just to be a Canadian writer, but to be a Canadian - to live in a country where we treat our writers like movie stars" (Bland).

However, linking a sense of identity to a distinctive Canadian environment was a difficult task for the mid-twentieth century thinkers and artists, bequeathed as they were with (the burden of) a double colonial legacy, and concerned with the threat of an ever-expanding U.S. cultural and economic influence permeating society. Northrop Frye famously articulated this challenge as a question when he argued that "Canadian imagination has been profoundly disturbed, not so much by our famous problem of identity, important as that is, as by a series of paradoxes in what confronts that identity. It is less perplexed by the question "Who am I?" than by some such riddle as "Where is here?"” (Frye, 1971: 220). Along similar lines, Margaret Atwood contends in Survival - the thematic guide she was commissioned to write to help implementing a new teaching curriculum with Canadian content - that "Canada is an unknown territory for the people who live in it... a state of mind... in which we find ourselves lost" (Atwood, 1972: 18). The task of writers and critics, Atwood believes, is that of mapping a "geography of the mind" that may give rise to what Benedict Anderson has termed and 'imaginary community':

What a lost person needs is a map of the territory, with his own position marked on it so he can see where he is in relation to everything else. Literature is not only a mirror; it is also a map, 
a geography of the mid. Our literature is one such map, if we can learn to read it as our literature, as the product of who and where we have been. We need such a map desperately; we need to know about here, because here is where we live. For the members of a country or culture, shared knowledge of their place, their here, is not a luxury but a necessity. Without that knowledge we will not survive. (Atwood, 1972: 17-18)

The immediate success of Atwood's seminal work led to the hegemony of an English-Canadian thematic criticism that held the North and the Canadian wilderness as the unifying cultural tropes, linked to Northrop Frye's notion of the Canadian 'garrison mentality' and to Atwood's 'survival', and contributed to the construction of a widely accepted periodicizing schema for Canadian literary criticism and for Canadian literature that, as Imre Szeman points out, "mirrors the one offered by Said for postcolonial literature in general. There is, first, a nationalist phase of Canadian literature and criticism: a crude, perhaps necessary phase of cultural self-assertion that is now seen as definitively superseded. In its place, there is a more savvy, self-confident criticism that does not see the need to produce in the field of literature a national culture consonant with the demands of the Canadian state" (Szeman, 2003: 157).

Frank Davey's 1974 influential essay "Surviving the Paraphrase", considered a 'seminal attack' on the nationalist criticism arranged along restrictive thematic lines, was an early point of inflexion, opening up the monolithic understanding of a nationalist literature to one that attended to aesthetic value as well as to discussion about the conflicting socio-political purpose of literature and criticism in the formation of citizenship. During the 1980s, coinciding with the rise of a multiculturalism consciousness in Canada and the related legislation strengthening Pierre Trudeau's Canadian federalism with 
the passing of the 1982 Canadian Charter of Rights and Freedoms and the 1988 Multiculturalism Act, other important events signaled the cultural transformations under way in Canada: from gender and race perspectives, the conferences Women and Words (Vancouver 1983), the Third International Women's Book Fair (Montreal 1988), and Writing Thru Race (Vancouver 1994) drew attention to the material effects of the imperial and colonial underpinnings of nation-building, contributing to emerging discourses that question the self-legitimization of the dominant master narratives. The triangulation between literature/culture, politics, and national identity production is, perhaps, nowhere as evident as when in 1988 - the same year the Canadian Multiculturalism Act "for the preservation and enhancement of multiculturalism" (Hutcheon, 1990: 368) was passed - on the occasion of Prime Minister Brian Mulroney's formal apology for the past injustices the Canadian state had inflicted on the Japanese Canadians, parts of Joy Kogawa's Obasan (1981), her bestselling novel about the plight of Japanese Canadians during and after World War II, were read in the Canadian House of Commons. The novel's astride position at the crossroads of history, politics and literature illustrates a shift whereby Canadian literature transitions from being an instrumental identity-building mechanism of the nation-state, to contesting, resisting, and troubling previous nation-state metanarratives. As alternative narratives from diverse cultural backgrounds carve their niche within the larger national narrative, Canada's strategy for nation building becomes that of regarding disunity as unity, as Robert Kroetch perceptively notes. For minoriticized cultures the challenge becomes at this point to avoid being coopted by what Stanley Fish labels 'boutique multiculturalism,' or by a multiculturalism discourse that could too easily veer toward ghettoizing celebrations of difference. Simultaneously, literary criticism increasingly turns from an attention to literature as exclusively a textual construct to a concern with the 
larger discourses within which literary production and reception are embedded.

The international recognition that Canadian literature achieved in the 1980s with the acclaim of books by authors such as Margaret Atwood, Alice Munro, Michael Ondaatje, or Yann Martel, led to the unqualified celebration of Canadian literature "going global" (Brandt, 2000: 106), as well as to renewed critical debates about what constitutes Canadian literature. Taking into account the multifarious geographic, cultural, racial, and ethnic provenance of many of the emergent writers at the time, some of the arguments revolved around the author's nationality, the setting of their works, and the language in which they wrote. The connection of writing (and writers) to place and space continued thus being of concern for critics, who were intent on demarcating the borderlines of Canadian literature. However, the heterogeneity of the writing from Canada also led to arguments about the important recognition of the links between Canadian writing and that of other regions contending with the legacy of colonialism; or to the dismissal of the nation as a relevant factor in the creation of literature. Thus, in Beyond the Provinces, David Staines declares, "We might well describe the history of Canadian literature... as the movement from colony to nation to global village, a global village being a nation beyond nationalism, where the nation's voices are so multifaceted that the distinction between international and national is no longer valid" (1995: 24). To Staines, Canada's cultural conundrum as expressed in Frye's aphorism - "Where is here?" - holds no currency in a world of supranational entities and global mobility that destabilizes the former fixity of center and margins. If, as he holds, "the centre, however indefinable, is none the less unmistakably both here and nowhere and everywhere" (1995: 8), Canada and Canadian culture move beyond the marginal parochialism of the 'provinces,' and onto the global map of intertwined cultural nodes. Yet, the so-called globalization of Canadian literature and culture appears 
nonetheless highly ambiguous and problematic. Whereas in Post-National Arguments: The Politics of the Anglophone-Canadian Novel Since 1967 Frank Davey sees Canada as a weakened "post-national state - a state invisible to its citizens, indistinguishable from its fellow, maintained by invisible political forces, and significant mainly through its position within the grid of world-class postcard cities" (1993: 266), the desire to accommodate global cultural contexts is just one more element accounting for the continuing angst over the intent and purpose of Canadian literature (Kamboureli, 2013: viii). As Cynthia Sugars remarks, the "rhetoric of globalization masks an underlying anxiety about Canadian national and postcolonial identity" (2006: 80), since relying on international success to become recognizable as a national literature/culture is a rather colonial move. Yet, contradictorily, Sugars adds, "This may also be what makes an erstwhile colony postcolonial: that is, when the local becomes identifiable and validated on the global scene" (2006: 82). In order to render the national international, the "national 'here', Sugars argues, must relinquish "its delimiting insistence on identity while maintaining its force as a meaningful vector of association" (2006: 82). Herb Wyile presents this quandary as a "balancing act: to make the study of writing in Canada relevant without capitulating to the forces of commodification, and to break out of homogenizing narratives of national literature while still nurturing writing grounded in Canada... and resisting the homogenizing pressures of global commodity culture" (2000: 222).

Thus, Smaro Kamboureli notes, today's criticism is more interested in a 'contextual approach' to literature, or rather, to 'literariness,' the compendium of interrelated, competing discourses, material conditions influencing the production of literature, as well as the linguistic and structural qualities of literary texts. Literariness understood as such a situational approach is, according to Roman Jacobson, the actual object of literary science, i.e., what makes a 
given work literary (Kamboureli, 2012: 6). Accordingly, Kamboureli contends, Canadian literary criticism has experienced "the shuttling of the critical gaze from the 'inside' to the 'outside' of the discipline along with the characteristic interdisciplinarity it involves" (2012: 27). This 'shuttling of the critical gaze' has led to several developments that are intrinsically related to a concern with "the Real, either in the form of cultural materialism or communal responsibility" (Goldman, 2007: 809). Together with the examination, revision and problematization of the discourse of conquest, settlement, appropriation, dispossession, and acculturation underpinning much nationalist Canadian literature, for example, contemporary Canadian literature and criticism are also intent on pondering the intertwining of globalization processes with local, regional and national conditions that inflect cultural production and the study of Canadian literature today. This self-reflexive move that Barbara Godard calls "metacritical reflection" relies on the idea that "methodology does more than reveal: it actually creates the object of study" (2008: 55), and is accompanied by an ethical thrust to practice criticism responsibly, to reach out to society by addressing issues of general social concern, such as racialization, indigeneity, citizenship and the role of the nation in the age of globalization, all of which held a marginal position or had been rendered invisible in the nationalist cultural discourses of the 1960s and 70s. ${ }^{45}$ This involves an epistemic shift in

\footnotetext{
45 Some ground-breaking collections have been published in the new millennium signalling advances in the dialogic debates re-evaluating and pushing forward the cultural power of literature and criticism over social transformation and institutions, foregrounding the interaction between creative writing, theoretical practice and the readerships they engage. Recent examples of this metacritical reflection are Laura Moss's Is Canada Post-Colonial?, Cynthia Sugars's Home-Work and Unhomely States, Diana Brydon, Manina Jones, Jessica Schagerl and Kristen Wardes's Poetics and Public Culture in Canada, Daniel Coleman's White Civility, Imre Szeman's Zones of Instability, Diana Brydon and Marta Dvořák's Crosstalk: Canadian and Global Imaginaries in Dialogue, and the trilogy by Coleman and Kamboureli, Retooling the Humanities (2011); Kamboureli and Zacharias, Shifting the Ground of Canadian Literary Criticism (2013); and Kamboureli and Verduyn, Critical Collaborations (2014),
} 
thematics, which at present, Kamboureli observes, "takes theme to be not a subject perceived as a stable or transparent construct that can be interpreted exhaustively and thus mastered but as a continuously unfolding constellation of interrelated (though perhaps on the surface disparate) issues that resist an exegetic approach" (2012: 32).

In the following section I offer a critical analysis of Will Ferguson's novel 419 that aims to exemplify the kind of critical and writerly practice that mobilizes thematics through ethical and political concerns that unsettle and attempt to move beyond the inherited parameters of national identity. In the process, I draw on several recent developments in Canadian writing and criticism, namely, the turn to ethics (Goldman and Kyser), the turn to affect/intimacy (Brydon, 2007; Kamboureli, 2011), and the turn to a spatial dialectics that pays attention to the situation of Canada and of Canadian literary production and criticism in a global context (Dobson, 2009; Wyile, 2011; Brydon and Dvořák, 2012; Fraile-Marcos, 2014).

Best known as a humor writer, Calgary author Will Ferguson won the 2012 prestigious Scotiabank Giller Prize for fiction with his thriller novel 419, titled after one of the most notorious global scams. Without totally renouncing the humor that Ferguson masters and for which he has been repeatedly awarded ${ }^{46}$, the novel is rather a sobering drama. It begins with the discovery that Henry Curtis's death has not been accidental. Instead, it is revealed that this retired Canadian teacher whose name evokes that of Kurtz, "the classic Euro-centric caricature of the African adventurer" (Ferguson, 2012: 407)

\footnotetext{
among a myriad other important works. The public reception of literature and the social creation of celebrity writers in Canada is the specific focus of scholarly books both in Canada - Lorraine York's Literary Celebrity in Canada (2007) and Margaret Atwood and the Labour of Literary Celebrity (2013) and outside Canada - Danielle Fuller and DeNel Rehberg Sedo's Reading Beyond the Book (2013).

46 Ferguson has won the Stephen Leacock Medal for Humour for his novel Happiness (2002), the travel memoirs Beauty Tips from Moose Jaw (2005) and Beyond Belfast (2010), and was shortlisted for the same award for How to Be a Canadian (2002) and Spanish Fly (2008).
} 
in Joseph Conrad's Heart of Darkness, has committed suicide after becoming the victim of an email scam known as '419' - after the section of the Nigerian Criminal Code that covers fraud (Ferguson, 2012: 111). From this point onwards, the lives of Henry's wife, Helen, and their children, Warren and Laura, cross and intertwine with those of a handful of characters in Nigeria, a place of variegated landscapes, riddled with cultural, religious, social and political conflicts, where the struggle for survival and endurance is a daily challenge. The novel's setting, therefore, shifts back and forth from an unnamed Canadian city, which is nevertheless identified as Calgary through certain urban landmarks, and the not so remote African landscapes. Actually, what the novel highlights is the (absolute?) erasure of national borders in a world where global human and capital mobility and electronic connectivity make up for a sort of global intimacy that raises important questions about security, justice, humanitarianism, and the foreign Other.

From a computer in Lagos, Western-educated Winston Balogun intrudes in Henry's anodyne life under a forged identity, pleading for help to save a troubled soul. Winston, who considers himself "a student of humanity" (Ferguson, 2012: 64) as well as an effective storyteller who fishes his victims with "words, with wonder" (Ferguson, 2012: 64), manages to create an intimate relationship with Henry by appealing concurrently to his compassion, an emotion that figures prominently in the construction of the Canadian ethos, as well as to his "thoughtful greed" (Ferguson, 2012: 64), as Winston puts it ${ }^{47}$.

\footnotetext{
${ }^{47}$ In addition to scholarly publications focusing on compassion from as diverse perspectives as politics, religion, health care, justice, education, literature or cultural studies (see, for instance, Acorn, Howard-Hassmann, Cooper and Rowlands, Beiser, Dallaire), recent news headlines reflect the public currency of the discussion about compassion in Canada, which is widely seen as one of the most cherished Canadian values: "Stephen Harper Conservatives dismantling Canada's compassion: Critics" December 9, 2013 http://metronews.ca/news/canada/878473/stephen-harper-conservatives-dismantling-canadas-compassion-critics/; "Governor General urges charity and compassion in New Year's message" December 27, 2013 http://o.
} 
Intersecting are also the stories of Ironsi-Egobia, the unscrupulous Ijaw gangster who controls the swindle business in Lagos and who forcibly recruits Winston to work for him. The atrocious violence of ethnic cleansing has shaped this despicable character, who as a young man witnessed how the army burned his Niger Delta town, Odi, to the ground and killed his parents. At the Christian seminary in Calabar where he was taken to afterwards he learned about the moral contradictions of love and retributive justice embedded in the Bible: "The Fathers... taught me the Gospel. Turn the other cheek. Love thine enemy. But they also taught: An eye for an eye" (Ferguson, 2012: 371-72). He chose to live by the latter. Though trafficking in falsehoods, Ironsi-Egobia does not tolerate anything but the truth from those at his service. Also from the Delta, Ironsi-Egobia's distant cousin Nnamdi has seen his own father poisoned by the encroachment of the Western oil industry in the region, and eventually resorts to black-market fuel smuggling to make a living. However, in contrast with Ironsi-Egobia's particular adoption of Western colonial creeds, Nnamdi takes moral guidance from his father's stories (Egberiyo), reflective of his village's spirituality, and ancestral experience, which prove syncretically resilient in the face of the current impact of global economics on the local and national scales (Ferguson, 2012: 165-76). Shaped after real-life Amina Lawal, the other main character is Amina, a young pregnant woman from the Sahel who is crossing the country on foot, running away from the fundamentalist Sharia laws that condemn women who bear children outside marriage to be stoned to death. When Amina's and Nnamdi's

canada.com/news/national/governor-general-david-johnston-new-year-message; or in initiatives such as that by Jannet Ann Leggett, founder of Canadians for Compassion, who has launched a national campaign to invite all Canadians to affirm the Charter for Compassion, and an initiative to collect 100,000 signatures from across Canada, calling upon Parliament to declare Canada as a compassionate nation, following the principles of the Charter for Compassion. http://www.wavesofcompassion.ca/ organizations.html 
paths intersect against this background of widespread violence and destruction, they envision a hopeful future together, represented by "Dreams Abound", the name of the truck that Nnamdi is driving at the time when he gives Amina a lift. All these characters' separate lives represent different worlds that nevertheless mirror each other.

I suggest that this novel problematizes the ethics of global cultural intimacy by means of its reflection on two different affective reactions to crime that can be identified through the discourses of retributive justice, on the one hand, and restorative justice, on the other. Although both retributive and restorative justice insist that wrongs must be put right, the former usually conflates justice with punishment and imprisonment in an attempt to inflict some sort of suffering on the wrongdoer as a means of paying back; in contrast, restorative justice is, according to Correctional Service Canada,

a philosophy and an approach that views crime and conflict principally as harm done to people and relationships. It strives to provide support and safe opportunities for the voluntary participation and communication between those affected (victims, offenders, and community) to encourage accountability, reparation, and a movement towards understanding, feelings of satisfaction, healing, safety and a sense of closure.

$\mathrm{RJ}$ is a non-adversarial, non-retributive approach to justice that emphasizes healing in victims, meaningful accountability of offenders, and the involvement of citizens in creating healthier, safer communities. (Correctional, 2014)

Therefore, restorative justice may appear as a better approach to crime, one that works "toward social justice and the broader goals of the creation of relations and communities of mutuality, respect, peace, harmony, and equality" (Acorn, 2004: 2), "a better means of ensuring accountability as well as effective deterrence" (Acorn, 
2004: 4). However, because restorative justice is deeply invested in intimacy between the victim and the offender, the emotional toll to be paid can be overwhelming and questionably fair for the victim, who must be determined to forgive.

While pointing out the dangers and potentialities of global intimacies, Ferguson's novel interrogates the possibility of engagement with the other as well as the limits of restorative justice in a contest that balances love and the need to do harm to others. By grappling with ethical complexity, 419 partakes of the recent turn to ethics and to affect in Canadian literature and criticism, which are not simply concerned with aesthetics and its "significance for the moral potential of the human being in a given community" (Eskin, 2004: 560), but with our relationship to the other.

If intimacy in the novel is linked to affect, emotions and feelings, it is also anchored in a history of global imperialism whereby the continuing exploitation of Africa by Western powers contends with the retaliatory criminal activities now practiced by some Africans under the pretence of redressing wrongs and enacting a sort of retributive justice. The 419 scam is just a piece in this scheme, problematizing and contesting Canada's self-portrait as a colonial victim in the national metanarrative with an African gaze that makes Canada complicit with the Western imperial and neoliberal projects of late capitalism that contribute to keep the continent in shambles. As Ironsi-Egobia explains, 419 is a business in retribution. After a survey of the plundering of Africa and the Americas carried out by various European Empires, Ironsi-Egobia rhetorically asks, "Why should these bankers, these slavers - these criminals - not return some of their lootings to the continent they have helped impoverish? Justice demands it. God demands it. The sins of the fathers shall be visited upon their children... Make no mistake, Adam, we are in the business of retribution. We are in the business of revenge" (Ferguson, 2012: 121). Eloquently, Ironsi-Egobia concludes that if 
Nigeria's is a 'culture of corruption,' Western culture is a 'culture of greed,' and the duped Westerners, or mugus, who agree to illegal schemes to take money out of a "poverty-stricken nation" (122), profiteering on the country's hardships, are criminals, too, "Aspiring criminals, but criminals still. Are they not accomplices as much as they are victims?" (Ferguson, 2012: 122). Thus, Ironsi-Egobia, whose adopted name works as an incantation meaning 'money come to me' (Ferguson, 2012: 117), rules himself by the Biblical "An eye for an eye, a tooth for a tooth" dictum (Exodus 21:24; Leviticus 24:20; Deuteronomy 19:21) that conflates justice with punishment and the infliction of suffering on the wrongdoer (Ferguson, 2012: 372).

In contrast with Ironsi-Egobia's portrayal of Westerners, Henry Curtis appears as a man of strong ethical principles that clash with any sense of justice based on personal profit or benefit. This personality trait comes to the surface when Laura, his free-lance copyeditor daughter, remembers the time when, as a child, she found a twenty-dollar bill at the Stampede and her father, after asking a number of people around, made her hand it in to a teenage boy who claimed it was his, though it was clear that he was lying. When Laura protested, Henry replied that even when the money was not probably his, "it definitely wasn't ours" (Ferguson, 2012: 31). Laura gets another glimpse at Henry's sense of justice when she first moved away from home to go to university. Henry drives from Calgary to Winnipeg to celebrate Thanksgiving with her, and after he leaves, Laura finds among her notes for a Philosophy essay she was writing, his mystifying rewriting of the ancient maxim Let justice be done though the heavens fall!:

Let Heaven be done, though justice falls.

She'd puzzled over this, her father's inversion of heaven and justice, of love and retribution, of forgiveness and reprisal. (Ferguson, 2012: 36) 
Clearly, Henry favours an authentic experience of mutuality, equality, respect, peace, and harmony among individuals, rather than a sense of justice that relies on punishment or revenge for accountability, regardless of consequences.

The news about the email scam that leads Henry to kill himself in despair (Ferguson, 2012: 78) causes an emotional upheaval in his intimate family circle. Yet, whereas his wife Helen quietly accepts her lot as a destitute grandmother who has to move to her son's basement because her savings and house are gone, Henry's children Warren and Laura react very differently. Warren readily and boisterously voices his anger against the cons, against the state forces who did not protect his father, against the bank, and against the Nigerian government. When it becomes clear that Henry's death will be ruled as suicide, and that the Canadian police is going to close the case, unable to take the cons to justice, Warren resorts to "Scambaiting" (Ferguson, 2012: 270) as his way of doing justice: "'Payback,' he explained. 'For Dad" (Ferguson, 2012: 270). As he explains Laura, scambaiters "police the net, set up traps", and when "these 419 weasels come calling, we take the bait. Instead of hitting DELETE, we reply" (Ferguson, 2012: 271). Thus, they intercept 419 cons to tease, ridicule, and expose them on the internet: "The trick is to answer with the most outlandish stories you can come up with, drag it out, waste their time, and then post the entire thing online" (Ferguson, 2012: 271).

Unlike Warren, who vents his anger and then enjoys outplaying the scammers at their own game, Laura remains numb with grief and emptiness until, pondering the idea that "Language. Reveals as much as it conceals" (Ferguson, 2012: 258), she begins entertaining the idea that by scrutinizing the language used in the emails his father received, she could track down the person who wrote them, contact him and travel to Nigeria to do justice. However, again unlike her brother, Laura's sense of justice at this point is more 
restorative than punitive, centered on making the criminal look her in the eye and acknowledge the damage he has done. Her primary concern, therefore, is not to get her parents' money back - "What if,' Laura asked, 'it wasn't about the money?'” (Ferguson, 2012: 139) - but to exact the con's recognition of accountability for Henry's death (Ferguson, 2012: 79). Laura succeeds in her objective once she finds and gets in touch with Winston by mimicking his methods. Competing with the 419ers in cunning and audacity, she creates a false identity for herself and makes up a story that justifies her trip to Nigeria. The setting she eventually chooses to reveal her true mission to Winston is the intimate space of his parents' home. During the small-talk conversation that takes place between them, Laura's words constitute a swirling subtext that simultaneously informs, threatens, and seeks his empathetic response:

You don't realize how fortunate you are, Winston. Both your parents are still alive... My dad died because of 419. He was killed by Nigerians... My father had his savings stolen, he lost his home, his life. My mother is living in my brother's basement now. And the man who is responsible for this needs to know. He needs to know what he's done, he needs to make amends. I have come to Nigeria to find him. (Ferguson, 2012: 341)

As Laura's mission dawns on Winston, he becomes a reflection of cornered Henry Curtis before he committed suicide. Laura can read Winston's affective reaction in his eyes: "panic, fear, bottled rage. It was the look of a man being driven off an embankment, a man falling through darkness" (Ferguson, 2012: 341). However, Laura is not content with placing Winston on the same spot he put her father. She needs to move him, to provoke his repulsion for the damage he has caused and to eventually make him accept his accountability. For that, she confronts Winston and his parents with a police photograph 
of the accident scene: "Her father's pulped features, face smeared, a mouth filled with blood, soft flesh ruptured, an arm dangling, barely attached" (Ferguson, 2012: 342). Although Laura succeeds in prompting Winston's mother's empathetic tears and his father's wish to catch the miscreant and have him sent to jail, Winston, refuses to feel anything beyond fear, and even rejects Laura's accusation that he is "a thief and a murderer": "hold your tongue, or I will cut it from your mouth. I am not a thief, nor a murderer. I am an entrepreneur" (Ferguson, 2012: 344). The discourse of violent neoliberal capitalism that, incidentally, resembles Warren's unscrupulous market-oriented one, thus interrupts the transaction in intimacy that Laura had been building up during their visit to his parents'. When Winston insists that their business is over, Laura lets rage overcome her, demanding the impossible, that he gives her father back to her. Appealing to his intimate emotions, Laura threatens with revealing his deeds not just to the EFCC (Nigerian Economic and Financial Crimes Commission), but even more importantly for him, to his parents. Understanding the position Laura is pushing him into, Winston then tries to delegitimize Laura's claims of intimate emotional reparations by moving from the personal to the communal and historical: “Is this what you want? Reparations? From Africa? Justice - from Africa? Nigeria is not your playground, madam. Africa is not some sort of - of metaphor" (Ferguson, 2012: 344). If Winston seeks sanction for his actions by turning Henry Curtis into a symbol of the continued exploitation of Africa by an unscrupulous, greedy West - "'Your father died from terminal greed, madam'” (Ferguson, 2012: 344) - Laura refuses to let her father be co-opted in this contest of retaliatory justice: “My father,' she shouted, 'was not a metaphor! Give him back to me!'” (Ferguson, 2012: 345). However, when Laura understands the futility of her attempts to make Winston accountable for her father's death, thereby deterring him from continuing in the 419 business, she herself turns to retaliatory justice, battling against Winston's threats 
- "We are mafia! We will ruin you, we will leave your life in tatters! You will die in Lagos!" (Ferguson, 2012: 348) - with extortion. After Laura manages to rip him off, she hands him in to security. Yet, in her self-righteousness, she fails to discern between who really deserves to be punished and who does not, making a serious blunder when she denounces Nnamdi, who had Ironsi-Egobia's order to kill her, but decides that he cannot do it. As a result, Nnamdi dies a horrible death at the hands of Ironsi -Egobia, who burns him alive as a punishment for his disobedience, as well as to warn all those under his rule of the consequences of disregarding his orders with moral scruples. Nnamdi's decision to put his own life at stake rather than killing another human being, even if to save his own child's life - "He might die for his child. But he wouldn't kill" (368) - makes him the most ethical figure in the novel. Like Winston before, Laura rejects accountability for Nnamdi's death, blaming Winston instead: "He did this. He killed the boy with the beautiful smile, not me" (Ferguson, 2012: 380). However, does not this turn of the tables situate her at the same moral level as the criminals from whom she seeks retribution? This is implied in the lyrics of the popular song that she hears on the radio in Lagos and later on evokes as she feels safe in the plane that takes her back to Canada: “'419, play the game; 419, all the same,' And threading through it a question: "Who is the mugu now?" (Ferguson, 2012: 385). The spiral of death and violence engendered by notions of retributive justice is complete when even Amina is trapped in the circle of revenge after learning that Nnamdi has been murdered for sparing Laura's life: "Loss demands repayment, and she turned back to Ironsi-Egobia, spoke in sobs. 'The oyibo. She has to die too. Don't let her to live [sic]"” (Ferguson, 2012: 379).

While the immorality of Ironsi-Egobia is simply beyond hope, the novel offers the possibility of redemption for both Henry Curtis and his daughter. Like Nnamdi, Henry appears as the father who chooses 
to die in order to protect his family from bankruptcy and from the 419 hired assassins. His moral stature is somehow ambivalently reaffirmed at the end when his wife Helen dissolves any doubts Laura might entertain about her father's reasons to be tricked into the 419 scam: "I don't think it was the money, no. I think it was the girl. I think your father wanted to be a hero to someone, just once'" (Ferguson, 2012: 390). As a result, Henry's nature is restored as that of a compassionate rather than greedy man, moved by the forged story of a helpless young woman trapped in a far-away land. Similarly, and following his example, Laura performs a sort of restorative justice when, rather than keep the money she got from Winston, she decides to send it to Amina and her child in Nigeria and sponsor them to enter Canada as refugees, thus contributing to provide them with a more hopeful future. Choosing love over retribution, Laura seems to act out of a need to somehow repair Amina's loss of Nnamdi, for which she is partly responsible. When Amina and her son do not show up at Calgary airport, and Laura understands that she has been tricked, she smiles, feeling that "her father would have been proud of her nonetheless" (Ferguson, 2012: 391), finally understanding her father's ethics that privileges Heaven over justice. Ferguson avoids a condescending, paternalistic, and ethnocentric ending by stressing until the end Amina's agency, her determination to build up her own life in Nigeria rather than in Canada, and very likely using Henry's money to set shop at Lago's market, thereby realizing her dream to become an independent and self-sustaining woman.

Will Ferguson's rendition of global intimacy delves, therefore, in the connection between literature, storytelling, ethics and affect. The novel's nuanced representation of violence, empathy, complicity, humanitarian responsibility, justice and accountability captures a range of concerns of great currency in a Canadian society that is inescapably confronted with negotiating its position in a glocal world 
of porous national borders. Intimacy is paired with globalization when global crime and violence toward people and the environment irrupt in the private spheres of the protagonist characters, showing that "global political economic conditions have profound effects on human relationships" (Pratt, et al. 2012: 31) and on their ethical understanding of justice. The novel reflects a neoliberal hyper-connected global world where the state mechanisms of justice fail the citizen. Thus, if the Canadian police investigation of Henry Curtis' death reaches a standstill due to legal, political and financial encumbrances to find and take the Nigerian con men to justice, in Nigeria the violence and widespread corruption caused by the overlapping interests of the state, the international oil companies, the local war lords, among other forces, make it even more difficult for justice to be achieved. It is then left to the individual to either resign or seek to do justice on his/her own, with the chances that this may entail the renewal of circles of violence and victimage.

If, as Michael Eskin argues, "it is the singular encounter between reader and text-as-other, soliciting a singularly just response on the reader's part that is at stake in 'ethics and literature'" (2004: 560), the experience of reading 419 leaves the reader pondering the complexity of human suffering and ethical engagement resulting from new forms of global intimacies marred by long histories of global economic exploitation and geopolitical imbalances between North and South, the West and the rest of the world. While the novel does promote bonds of universal love between self and others, Ferguson also underlines the prevalence of retributive justice when people fall short of admitting empathy, accountability, or genuine forgiveness. Narrative and storytelling may be hijacked by characters of various ethical standards to try to justify their positions as just. Yet, the novel does not succumb to this cooption but provides the reader with the necessary distance to assess the different degrees of victimization and wrongdoing in which individuals and global 
actors alike are caught, thus underlining the complexities of the ethics of global intimacy.

Ferguson's novel incites a kind of metacritical approach that relies on interdisciplinarity, illustrating the recent shifting of the ground in the study of Canadian literature, from the inside to the outside of the discipline. Far from reasserting a unified vision of Canadian identity, based on the idiosyncrasy of the Canadian landscape and Canadian history, 419 is firmly anchored in the questions raised by a highly mobile and hyperconnected world in which citizens must rework their relation and ethical responsibility to the Other not just through ideological critique, but also though the spurring of the imagination and a revived poetics.

\section{References}

Acorn, Annalise E. (2004). Compulsory Compassion: A Critique of Restorative Justice. Vancouver: University of British Columbia Press.

Anderson, Benedict (2006). Imagined Communities: Reflections on the Origin and Spread of Nationalism. London: Verso.

Atwood, Margaret (1972). Survival: A Thematic Guide to Canadian Fiction. Toronto: Anansi.

Bhabha, Homi (1990) (ed.). Nation and Narration. N. Y.: Routledge.

Beiser, Morton (1999). Strangers at the Gate: The "Boat People's" First Ten Years in Canada. Toronto: University of Toronto Press.

Bland, Jared (2013). "Edmonton author Lynn Coady wins 2013 Giller Prize". Globe and Mail 05 Nov. Web. 01 Sept. 2014.

Brandt, Di (2000). "Going Global". In: Essays on Canadian Writing 71, pp. 106-113 .

Brydon, Diana (2007). "Dionne Brand's Global Intimacies: Practising Affective Citizenship”. In: University of Toronto Quarterly 76.3, pp. 990-1006.

Brydon, Diana, Manina Jones, Jessica Schagerl, and Kristen Warder (2007). "Introduction. Surviving the Paraphrase: Poetics and Public Culture in Canada". In: SCL/ÉLC Special Issue. Poetics and Public Culture in Canada 32.2, pp. 7-27.

Brydon, Diana, and Marta Dvořák (2012) (eds.). Crosstalk: Canadian and Global Imaginaries in Dialogue. Waterloo: Wilfrid Laurier University Press.

Coleman, Daniel (2006). White Civility: The Literary Project of English Canada. Toronto: University of Toronto Press. 
Coleman, D.; Kamboureli, S. (2011). Retooling the Humanities. Edmonton: University of Alberta Press.

Cooper, Andrew F.; Rowlands, Dane (2006) (eds.) Canada Among Nations, 2006: Minorities and Priorities. Montreal: McGill-Queen's UniversityPress.

Correctional Service Canada (2014). "About Restorative Justice". 13 Jan. Web. 10 Oct. 2014.

Dallaire, Michael (2011). Teaching with the Wind: Spirituality in Canadian Education. Lanham, Maryland: University Press of America.

Davey, Frank (1976). "Surviving the Paraphrase". In: Canadian Literature 70, pp. 5-13.

- (1993). Post-National Arguments: The Politics of the Anglophone-Canadian Novel since 1967. Toronto: University of Toronto Press.

Dobson, Kit (2009). Transnational Canadas: Anglo-Canadian Literature and Globalization. Waterloo: Wilfrid Laurier University Press.

Eskin, Michael (2004). “The Double 'Turn' to Ethics and Literature?”. In: Poetics Today 25.4, pp. 557-72.

Ferguson, Will (2012). 419. Toronto: Penguin Canada.

Fish, Stanley (1997). "Boutique Multiculturalism, or Why Liberals Are Incapable of Thinking about Hate Speech". In: Critical Inquiry 23.2, pp. 378-95.

Fraile-Marcos, Ana María (2014) (ed.). Literature and the Glocal City: Reshaping the English Canadian Imaginary. New York: Routledge.

Frye, Northrop (1965). "Conclusion". In: Klink, Carl F. (ed.). Literary History of Canada. Toronto: University of Toronto Press, pp. 333-64.

(1971). The Bush Garden: Essays on the Canadian Imagination. Toronto: Anansi.

Fuller, Danielle and DeNel Rehberg Sedo (2013). Reading Beyond the Book: The Social Practices of Contemporary Literary Culture. New York: Routledge.

Godard, Barbara (2008). Canadian Literature at the Crossroads of Language and Culture. Ed. Smaro Kamboureli. Edmonton: NewWest.

Goldman, Marlene; Kyser, Kristina (2007) (eds). The Ethical Turn in Canadian Literature and Criticism. Special Issue University of Toronto Quarterly 76.3.

Howard-Hassmann, Rhoda E. (2003). Compassionate Canadians: Civic Leaders Discuss Human Rights. Toronto: University of Toronto Press.

Hutcheon, Linda; Richmond, Marion (1990) (eds.). Other Solitudes: Canadian Multicultural Fictions. Toronto: Oxford University Press.

Kamboureli, Smaro (2013) (ed.) Writing the Foreign: Canadian Literature and the Politics of Representation and Empathy. Spec. issue of University of Toronto Quarterly, 82.2, pp. 86-372.

Kamboureli, Smaro; Miki, Roy (2007) (eds.) Trans.Can.Lit: Resituating the Study of Canadian Literature. Waterloo: Wilfrid Laurier University Press.

Kamboureli, Smaro; Zacharias, Robert (2012) (eds.). Shifting the Ground of Canadian Literary Studies. Waterloo, ON: Wilfrid Laurier University Press. 
Kamboureli, Smaro; Verduyn, Christl (2014) (eds.). Critical Collaborations: Indigeneity, Diaspora, and Ecology in Canadian Literary Studies. Waterloo, ON: Wilfrid Laurier University Press.

Kroetch, Robert (1989). "Disunity as Unity: A Canadian Strategy". In: The Lovely Treachery of Words: Essays Selected and New. Toronto: Oxford University Press, pp. 21-33.

Moss, Laura (2003) (ed.). Is Canada Postcolonial? Unsettling Canadian Literature. Waterloo: Wilfrid Laurier University Press.

Moss, Laura; Sugars, Cynthia (2009) (eds.). Canadian Literature in English: Texts and Contexts. Vol. II. Toronto: Pearson/Longman.

Pratt, Geraldine; Rosner, Victoria (2012) (eds.) The Global and the Intimate: Feminism in Our Time. N.Y.: Columbia University Press.

Staines, David (1995). Beyond the Provinces: Literary Canada at Century's End. Toronto: University of Toronto Press.

Sugars, Cynthia (2006). "World Famous Across Canada': National Identity in the Global Village”. In: Global Fissures: Postcolonial Fusions. Amsterdam: Rodopi, pp. 79-102.

Sugars, Cynthia (2004) (ed.). Unhomely States: Theorizing English-Canadian Postcolonialism. Peterborough: Broadview.

- (2004) (ed.). Home-Work: Postcolonialism, Pedagogy, and Canadian Literature. Ottawa: University of Ottawa Press.

Sugars, Cynthia, and Gerry Turcotte (2009) (eds.) Unsettled Remains: Canadian Literature and the Postcolonial Gothic. Waterloo: Wilfrid Laurier University Press.

Sugars, Cynthia; Moss, Laura (2009) (eds.). Canadian Literature in English: Texts and Contexts. Vol. I. Toronto: Pearson/Longman.

Szeman, Imre (2003). Zones of Instability: Literature, Postcolonialism and the Nation. Baltimore: Johns Hopkins University Press.

Wyile, Herb (2000). "From Roots to Routes: Cultivating Canadian Writing in an Electronic Age". In: Essays on Canadian Writing 71.

Wyile, Herb (2011). Anne of Tim Hortons: Globalization and the Reshaping of Atlantic-Canadian Literature. Waterloo: Wilfrid Laurier University Press.

York, Lorraine (2007). Literary Celebrity in Canada. Toronto: University of Toronto Press.

(2013). Margaret Atwood and the Labour of Literary Celebrity. Toronto: University of Toronto Press. 